A Stakeholder Perspective on Buyer-Supplier Conflict 


\title{
A Stakeholder Perspective on Buyer-Supplier Conflict
}

\author{
Abstract \\ This paper seeks to investigate how stakeholder power and an organization's pursuit of \\ legitimacy influence its reaction to conflict with a supplier. We conduct an empirical study \\ among travel agents and tour operators to test the relationship between conflict and \\ stakeholder power and legitimacy derived from three different stakeholders. Our findings \\ imply that power has a dual role. Whereas supplier power reduces buyer-supplier conflict, \\ stakeholder power increases it. Moreover, this study shows that the quest to achieve greater \\ legitimacy from the firm's competitive arena increases conflict. This paper is one of the few \\ that test stakeholder theory empirically. We demonstrate that stakeholder theory provides \\ additional explanations above the hitherto taken dyadic approach towards understanding \\ conflict. This paper also shows that power can simultaneously reduce and increase conflict \\ depending on which party possesses power. Greater supplier power decreases conflict while \\ greater stakeholder power and stakeholder derived legitimacy increases it. Therefore, \\ organizations have to balance their stakeholder and supplier interests.
}


Channel conflict received considerable interest in the 1970s and 1980s and significant advancements have been made towards its understanding. Conflict results when one party perceives that its interests or goals are being opposed, impeded or negatively influenced by the other party (Jap and Ganesan, 2000). Much of the existing literature explains channel conflict based on the power of one channel member over another, thereby approaching channel conflict as a dyadic issue (Schul and Babakus, 1988, Gaski, 1984, Hibbard et al., 2001). However, relationships between organizations do not operate in isolation. In their cooperation, third parties, such as customers or competitors, may influence buyers and suppliers. For example, Apple has had long lasting conflict with a number of music companies about digital rights management. ${ }^{1}$ Apple's iTunes store, a reseller of music, wanted to sell digital music without the copy protection mechanisms the music companies insisted on. In 2007 Apple responded to this conflict by dropping digital rights management for some of its music offerings with the argument being that customers' power, as customers could choose alternative offerings without copy protection, was a major reason for their move. Similarly, in 2003 Marriott hotels faced the discounted sale of hotel rooms by Expedia (at the time owned by Interactive Corp.). ${ }^{2}$ Marriott engaged in conflict with Interactive Corp. by introducing a lowest price guarantee for customers booking a room directly from them. The power that customers as important stakeholders have to choose for the lowest price available was an important trigger of Marriott's reaction to this buyer-seller conflict. Whereas the literature on channel conflict in marketing suggests that supplier power in dyadic relations is likely to reduce a buyers' response to conflict (e.g., Anderson \& Weitz 1989), the role of stakeholders on conflict has rarely been considered yet can be important as the above examples illustrate. The reason for this importance is that engaging in conflict with a supplier can satisfy a powerful stakeholder or enhance the firm's acceptance by a 
stakeholder (i.e. enhance legitimacy). As such, it may be beneficial for an organization to engage in conflict. Consequently, adopting an extra-dyadic perspective to study channel conflict may augment our understanding of the drivers of conflict. In this paper, we therefore address how stakeholders outside of the buyer-supplier relationship such as customers, competitors, and industry associations influence conflict between a buyer and its supplier. We do so from the perspective of a buyer and focus on the severity of the organization's response in terms of how firm, uncompromising, tough, and decisive the reaction to a conflict issue with its supplier is.

Recent advancements in the understanding of networks have allowed us to study channel phenomena, including channel conflict, beyond the dyadic perspective. In particular stakeholder theory is well suited as stakeholder theory is about managing conflict stemming from divergent interests (Frooman, 1999, Voss et al., 2005). Moreover, stakeholder theory identifies which groups influence a focal organization and which managerial action is taken in response to those groups (Freeman, 1984). As such, stakeholder theory offers insight into the processes by which intra-dyadic issues, such as buyer-supplier conflict, are influenced by others who may have divergent interests (Frooman, 1999). Because we study how customers, competitors, and suppliers influence conflict, we contribute to the understanding of the top Marketing Science Institute research priority for 2006-2008, which is to advance the understanding of connections between suppliers, buyers, customers, and competitors (Marketing Science Institute, 2006).

Moreover, by using stakeholder theory to investigate channel conflict we answer to the many calls to expand channel research to include extra-dyadic perspectives (e.g., Levy and Grewal, 2000, Frazier, 1999). More specifically, it allows us to investigate if power and legitimacy, two core concepts in stakeholder theory, provide additional explanatory power over the hitherto investigated power-conflict relationship in an intra-dyadic setting. Unlike in a dyadic 
setting, we show that power can simultaneously positively and negatively influence conflict depending on which party holds power. Furthermore, we show that legitimacy sought from stakeholders provides a reason why conflict may be rational as organizations strive not only for economic but also social fitness (Grewal and Dharwadkar, 2002). An additional contribution of the present research is that we investigate whether stakeholder theory can be usefully applied empirically to relatively common organizational issues, such as a firm's reaction to conflict, rather than specific issues, such as boycotts, that have characterized much of the previous stakeholder research.

Next, we present our conceptual arguments on how conflict can be explained. We then discuss the empirical study, set in the context of the travel industry. We conclude with results and their implications.

\section{Hypotheses}

The dyadic perspective: the influence of supplier power on supplier-buyer conflict The marketing literature on channel conflict has been dominated by studies taking dyadic perspectives and overwhelmingly this research suggests that power is a major antecedent of channel conflict in buyer-supplier relationships (Gaski 1984). Although we recognize that there has been some discussion on the direction of the power-conflict relationship (Etgar 1978), there are strong arguments to expect greater relative supplier power to reduce a buyer's response to conflict. First, organizations that are more powerful usually possess vital resources. This makes it difficult for the exchange partner to retaliate to any conflict started as it may threaten the availability of the very resource on which it is dependent. Second, an increased noncoercive power of one party over another increases incentives for cooperation and normalization of the exchange relationship, which in turn tempers manifest conflict (Gundlach and Cadotte, 1994). Moreover, research in psychology has also shown that if there 
is a greater relative power of one party over another, conflict is reduced (Lawler et al., 1988). Hence,

H1: Relative supplier power decreases the severity of the buyer's reaction to conflict with that supplier.

The extra-dyadic perspective: the influence of stakeholder power and legitimacy on supplierbuyer conflict

Effects from outside of the dyadic, buyer-seller, relationship may influence conflict. We propose that, even controlling for the effect of relative supplier power, having more powerful stakeholders increases conflict. Stakeholders are defined as any group or individual who can influence, or is influenced by, the achievement of the organization's objectives (Freeman, 1984). As this definition is very broad, subsequent scholars have narrowed the definition of stakeholders down to those individuals or groups who possess power, legitimacy, or urgency relative to an organization. It is also this "narrow view" that we adopt in this paper.

Stakeholder theory was introduced by Freeman (1984) to study the conflict organizations face in satisfying the needs of shareholders that wanted high returns, while simultaneously using strategies to reach that end that were deemed acceptable by various individuals, organizations, and groups (Harrison and Freeman, 1999). Thus stakeholder theory is about conflicts between self-interest and "other regarding" interest (Agle et al., 1999). One of the key issues this theory focuses on is if, and how, stakeholders influence organizational outcomes (Berman et al., 1999, Harrison and Freeman, 1999). Stakeholder theory suggests that the means stakeholders have to influence organizational outcomes are based on power and legitimacy because without having at least some legitimacy or power, a stakeholder cannot influence a focal organization (Mitchell et al., 1997). Based upon previous research 
(Maignan and McAlister, 2003) and interviews with five managers in the travel industry, competitors, customers, and the industry association were identified as important stakeholders. That is, based on the interviews, competitors, customers, and the industry association appeared to have power and/or legitimacy relative to most travel agents and tour operators). Consequently, we take power and legitimacy for each of the three identified stakeholders into account. In figure 1 we show each of these stakeholders and also show how we expect these stakeholders to impact conflict.

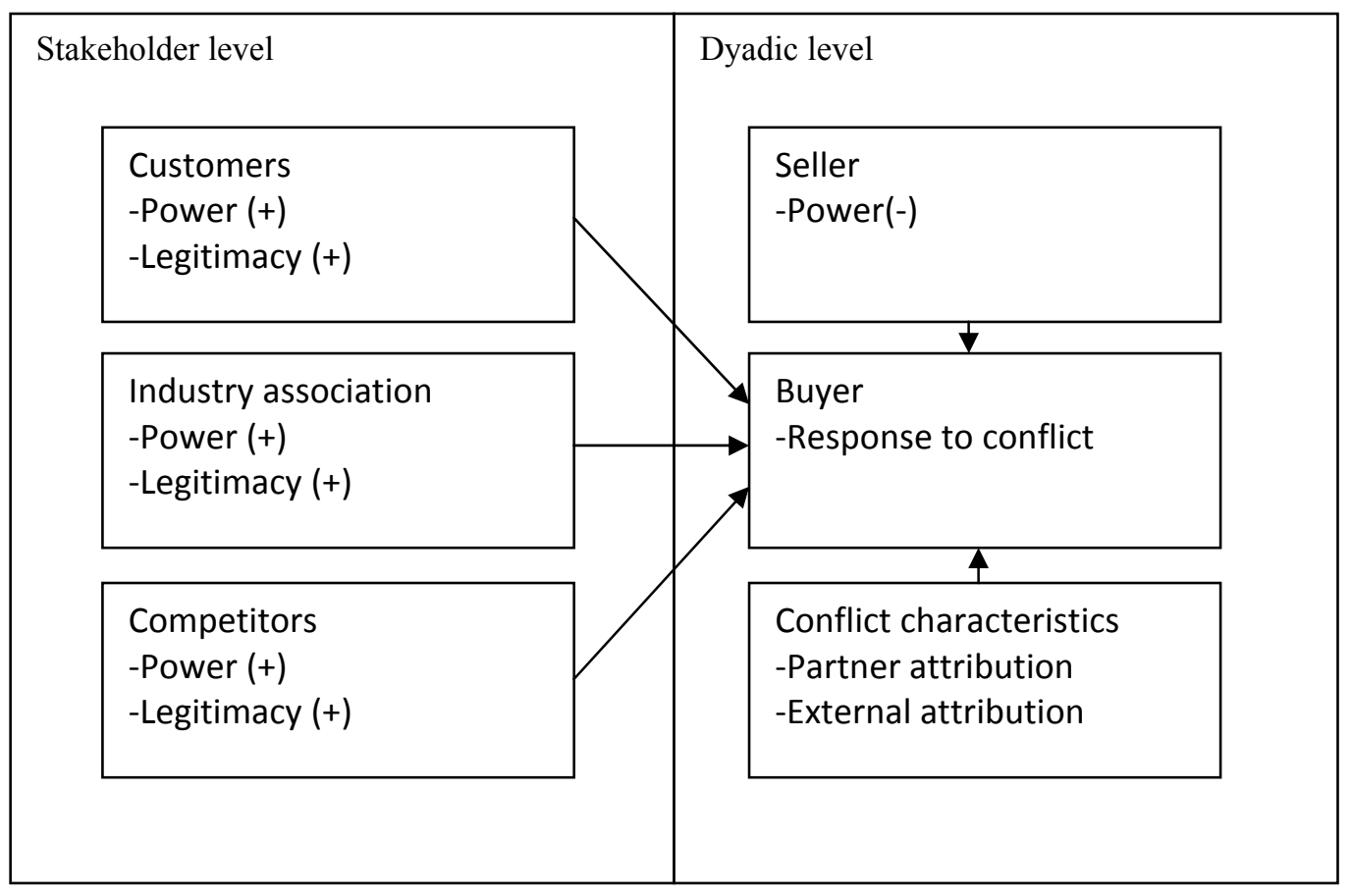

Figure 1: The effects of stakeholder on conflict

Power in a dyadic setting is the relative strength of organization A over B. In a network setting, stakeholders can influence a focal organization if they possess some degree of power (Maignan and Ferrell, 2004, Oliver, 1991). This stakeholder power becomes especially important if stakeholders have divergent interests, for example if customers wish to lower prices and an industry association seeks to increase prices. Power originates from the possession of important resources controlled by stakeholders such as expertise, coordination, 
and a target market, and stakeholders can influence organizations by withholding or threatening to withhold such resources. Because of this power, stakeholders can pressure an organization to do something its exchange partner may not necessarily want, thereby causing conflict with that partner (i.e. supplier). As powerful stakeholders are more salient to managers they are more likely to act upon pressure initiated by powerful stakeholders in order to satisfy their demand (Agle et al., 1999). Moreover, based on conflict spiral theory, one would expect that greater power of stakeholders result in increasing conflict between buyers and sellers. Conflict spiral theory suggests that retaliation is a central aspect of conflict where actions of one party (i.e. stakeholders) cause another party to retaliate. More precisely, the likelihood that stakeholders will introduce conflict issues, and the expectancy of an organization that this stakeholder will do so, increase if the stakeholder has more relative power over the organization (Lawler et al., 1988). The argument to this is that if stakeholders have more power, they are more tempted to use it because they expect a low likelihood of retaliation by the other party. However, once they use this power the organization may be tempted to retaliate to other parties. This greater use of their power can cause greater conflicts between the buyer and seller as stakeholder demands (e.g. adhering to industry regulations) can be conflicting to the functioning of the buyer-seller relationship (Kumar et al., 1998). An example where conflict between a buyer and seller was increased due to a powerful stakeholder is the case of StarKist where Frooman (1999) described how StarKist was pressured by an environmental group to change the way how suppliers of StarKist caught fish. In turn, StarKist pressured its suppliers, to change their fishing methods. The environmental group used their power in this case (by means of asking for consumer boycotts) to pressure StarKist to engage in conflict with its suppliers even though, as Frooman (1999), described these suppliers were very powerful.

Overall, we expect that more powerful stakeholders can increase channel conflict: 
H2a: Power of an industry association increases the severity of a buyer's reaction to conflict.

$\mathrm{H} 2 \mathrm{~b}$ : Power of competitors increases the severity of a buyer's reaction to conflict.

H2c: Power of customers increases the severity of a buyer's reaction to conflict.

In networks, organizations strive to enhance their perceived attractiveness (Anderson et al., 1994). This perceived attractiveness is the extent to which a firm believes that engaging in an exchange relation with a partner firm has, in addition to the effect on outcomes within the relation, an advantageous effect on the attractiveness of an organization as an exchange partner. As firms strive to enhance their attractiveness as an exchange partner so do they strive to obtain legitimacy. Legitimacy is defined as a generalized perception or assumption that the actions of an entity are desirable, proper, or appropriate within some socially constructed system of norms, values, beliefs, or definitions (Suchman, 1995). Seeking legitimacy is important as it helps organizations in 3 ways. Firstly, legitimacy, through the acceptance of an organization by its environment, facilitates operating in that environment. Secondly, seeking legitimacy also increases stability of the organization (Suchman, 1995, DiMaggio and Powell, 1983), which is something most organizations value. This stability of organizations is derived from the increase in trustworthiness, understanding, and credibility (Suchman, 1995) accruing from actions that are deemed to be legitimate. Thirdly, if a reaction to conflict is perceived to be a legitimate action, this will have an anticipated constructive effect on the attractiveness of an organization because the consequence is the acceptance of an organization by its environment (Deephouse, 1996). Seeking legitimacy may thus increase the severity of response to conflict. An example of how stakeholders can increase conflict is Virgin's reaction to the prices offered by music companies. ${ }^{3}$ The conflict 
issue was over the differential pricing of music by a number of music companies where Virgin felt it got a worse deal than its competitors did. Virgin's reaction to this conflict was to withhold payments to these music companies with the argument being that key stakeholders to Virgin, its competitors, got a better pricing deal. Thereby Virgin sought legitimacy for their claim of unfair pricing by referring to what its competitors get. If engaging in conflict, such as in the Virgin example, enhances legitimacy, it may provide a reason as to why conflict is beneficial and in the self-interest of organizations. The functionality of channel conflict has been acknowledged by many scholars (Brown and Day, 1981), but little attention is given as to what this functionality is. We suggest that an organization's quest for legitimacy may provide just such a reason as to why reacting to conflict may be functional. Therefore, we propose the following hypotheses:

H3a: Seeking legitimacy from an industry association increases the severity of a buyer's reaction to conflict.

H3b: Seeking legitimacy from competitors increases the severity of a buyer's reaction to conflict.

H3c: Seeking legitimacy from customers increases the severity of a buyer's reaction to conflict.

\section{Research Method}

We study the influence of stakeholders on the severity of reactions to conflict in the context of travel agents and tour operators in the Netherlands (SIC codes 4724 and 4725) which is also our sampling frame. This context is appropriate to study conflict because as it recently experienced a number of conflict issues, which facilitates respondents' recall. Moreover, the context of travel agents and tour operators is one where substantial variation exist in the size 
of its suppliers, thereby suggesting variation in the power these suppliers can exercise over these travel agents and tour operators. Moreover, substantial variation exists in the size of these agents and tour operators and their customers (ranging from individual travelers buying a single ticket to large corporate accounts), as well as that multiple industry associations exists. All, this suggests variation in the power these possible stakeholders have. As an initial step in the data collection process, we conducted interviews among travel agencies and their suppliers. This provided a general insight into the conflict issues present in the industry, as well as into their causes and consequences from both perspectives. The interviews revealed that both the buyer and supplier had a very similar perception of the issues over which they have conflict. These issues are similar to those found in previous research such as a lack of product or service availability, increases in prices charged, efforts of the supplier to sell products directly (i.e. the threat of disintermediation), and customer complaints that were passed on to the supplier.

\section{Data Collection Procedure}

The data were gathered using mail surveys based on the process lined out by Dillman (2000). Using the Dutch chamber of commerce database, we selected all organizations that were economically active from SIC codes 4724 and 4725 . Subsequently we called these organizations to 1) verify details, 2) ask for cooperation, and 3) ask for the name of an informant which, on the basis of a small number of prior interviews we identified as the CEO or director for smaller companies and the marketing or sales manager for larger companies. We approached these informants at the national level, and consequently had no more than one response per organization (defined at the legal level). We sent the questionnaires to 458 informants and a net response of 116 surveys, or $25 \%$, was obtained. As channel conflict is 
generally considered a sensitive subject, this response rate is satisfactory and compares favorably to the response obtained from most other channel studies.

Tests between early and late respondents revealed no differences between the characteristics of the organizations that were surveyed including organizational size and informant tenure and competence. Thus on the basis of the ideas of Armstrong and Overton (1977) nonresponse bias does not appear to be a problem. A stronger test was carried out to see if the population drawn from SIC codes 4724 and 4725 of the chamber of commerce database differs significantly from the sample obtained by comparing organizational size. We compared the average size of firms included in the chamber of commerce database to our sample obtained but found no difference, thus concluding that our sample appears representative of the population. In Table 1 we show organizational size statistics for our sample and the population.

The informants we surveyed were on average over 10 years in their current function, which is an indicator of their competency on the subject (Kumar et al., 1993). Consistent with this, the informants considered themselves to be knowledgeable about the relationships with the major suppliers of the organization (average $=5.7 / 7$-point Likert scale where 7 is the highest score). No responses from informants were deleted based on their reported competency.

\section{Measurement}

Multi-item measures are available for all the constructs necessary to test the hypotheses. An overview of all measures, together with the Cronbach alpha of the scale can be found in Appendix 1. In Table 1 we show a correlation matrix of all the constructs, together with their means and standard deviations and a number of sample and population statistics. 
Severity of conflict reaction is the severity of the response of the buyer over a conflict issue and is based on the scale of Antia and Frazier (2001). This scale assesses how firm, uncompromising, tough, and decisive the reaction to a conflict issue was. On average informants indicated, on a scale ranging from 4-28, a severity of 19.77 . Notice that this scale measures the severity of response and not if this response was positive or negative.

Power is based on the 2-item scale proposed by Ganesan which measures the supplier's or stakeholder's relative power over the buyer (1993). This scale is extended with one new item on the relative power of a supplier or stakeholder over the buyer. Care was taken that this additional item is consistent with Ganesan's power definition.

Legitimacy has been operationalized in two slightly different ways in the previous literature. Agle, Mitchell, and Sonnenfield (1999) operationalize the construct of legitimacy in the light of appropriateness and properness while Grewal, Comer, and Mehta (2001) operationalize legitimacy in terms of how actions would portray the organization towards other organizations. Consistent with our focus on explaining behavior we adopted Grewal, Comer, and Mehta's scale. We define legitimacy as a generalized perception that the actions of an organization are desirable, proper, or appropriate within some socially constructed system of norms, values, beliefs, and definitions (Suchman, 1995). Consistent with Grewal, Comer, and Mehta's scale the first two items measure the extent to which organizations mimic other organizations while the third item measures legitimacy as a motive.

We control for conflict attribution as in a network context the blame for conflict determines how it is evaluated and reacted to (Frazier, 1983). These attributions are most commonly classified in terms of self, partner, or external attribution (Scheer and Stern, 1992, Hibbard et al., 2001). As issues introduced by the buyer will not lead to reactions by this buyer, we focus on partner and external attribution. Both variables are measured using the 3-item scales of 
Hibbard, Kumar, and Stern (2001). These scales reflect who is responsible for the conflict from the perspective of the buyer.

We calculated Cronbach's Alpha coefficient to assess consistency and found coefficients that were satisfactory (ranging from .70 to .91). An assessment of unidimensionality using principal component analysis resulted in one-dimensional scales, which supports that we measure one underlying dimension per construct. We conducted a confirmatory factor analysis to assess fit of the indicators with the constructs. The resulting model $\left(\chi^{2}=579.10\right.$, $\mathrm{DF}=319, \mathrm{RMSEA}=0.076, \mathrm{CFI}=0.89)$ fits reasonably well.

Using the procedure of Fornell and Larcker (1981) we tested for discriminant validity of our measures by comparing the variance extracted from each pair of constructs to the squared correlation of the two constructs. Because in every case the variance extracted exceeded the squared correlation of the constructs, our results indicate that our measures display discriminant validity. The average variances extracted range from .50 to .87 (see diagonal of Table 1) and are acceptable.

\section{Results}

We tested the hypotheses described previously using ordinary least squares. The results are shown in Table 2.

-Take in Table (No. 2)

The findings suggest that increased power of the seller is associated with a weaker reaction to conflict, confirming extant research and supporting Hypothesis 1. Hypothesis 2 states that we expect stakeholder power to increase reactions to channel conflict. We find support that customer power $(\mathrm{H} 2 \mathrm{c})$ indeed increases channel conflict. Hypothesis 3 states that seeking stakeholder legitimacy increases channel conflict. We find support that seeking competitor legitimacy $(\mathrm{H} 3 \mathrm{~b})$ indeed increases channel conflict. The effect sizes of customer power and 
competitor legitimacy on the severity of conflict reaction ( 0.22 and 0.26 respectively) indicate relatively strong effects. Our findings suggest that one potential stakeholder, the industry association, has no influence but that the two other stakeholders, customers and competitors, do influence conflict, even if we control for the origin of the conflict. We find no empirical support to suggest that both legitimacy and power of one stakeholder simultaneously influence the focal organization to react to channel conflict.

A number of tests were carried out to analyze all interactions between the different attributions, power, and the stakeholder attributes but no patterns could be found.

\section{Discussion}

This research conforms to the calls of several channel studies to expand beyond the dyadic perspective that characterizes most existing marketing channel research. We show that stakeholder theory can be usefully applied to marketing channel research and that using a stakeholder approach provides additional insights over a dyadic approach. Specifically we find that the role of power differs for dyadic and extra-dyadic approaches. In a dyadic approach, more power of the partner is associated with a less severe reaction to conflict and in an extra-dyadic approach more power of a stakeholder is associated with a stronger response to conflict. The reason why we find that supplier power decreases conflict, while stakeholder power increases it may lie in the fact that it is generally easier to retaliate towards suppliers than it is towards stakeholders (Lawler et al., 1988). Moreover, the argument of conflict spiral theory is stronger if parties are more committed to use whatever power they have to reach their goals. Stakeholders may be more likely to use their power than suppliers because by their very nature suppliers are partially dependent on the business they do with their buyers whereas stakeholder may depend less on the organizations they are trying to influence. 
In addition, stakeholder theory allows us to identify the importance of legitimacy in explaining channel conflict. We find some support for the notion that seeking legitimacy is a motive for firms to react to channel conflict. As such, stakeholder theory provides an important mechanism to explain why conflict may be rational. According to Anderson, Håkansson, and Johanson (1994), firms aim to increase their attractiveness as an exchange partner. The constructive effects of seeking legitimacy, including an increased likelihood of organizational survival, acceptance of its environment, and an increased stability of the organization, may make an organization more attractive as an exchange partner. As we find power and legitimacy to influence conflict, we find support for Grewal and Dharwadkar's (2002) proposition that power and legitimacy of the network surrounding the organization influence intra-dyadic processes. Moreover, these findings also show that stakeholder theory can be usefully applied empirically for investigating conflict.

We found no effect of power or legitimacy with respect to the industry association. One possible explanation for this may be that the importance organizations attach to the industry association is much less than either that of their competitors or customers, which both are stakeholders that more directly influence the bottom line. This finding is in line with a 'narrow view' on stakeholders where only those organizations of direct economic relevance are deemed stakeholders (Mitchell et al., 1997). Consistent with the notion of market orientation that customers and competitors are at the core of a firm's orientation towards its environment (Narver and Slater, 1990), managers react to conflict more severely in the event that their customers are more powerful or that the firm can derive legitimacy from its competitors by doing so.

\section{Managerial Implications}


Channel conflict is a pervasive issue in many buyer-seller relationships. Although conflict usually has a negative connotation, our findings suggest that there is a positive side to conflict as conflict can enhance a firm's legitimacy. That is, conflict may increase the acceptance to certain stakeholders of an organization. We find that particularly the acceptance of an organization by its competitors is enhanced if a firm reacts more strongly to conflict. This finding points out that regardless of the positive or negative effects of conflict in the buyerseller relationship itself, conflict may have beneficial effects (increase legitimacy, the acceptance of an organization) outside of it.

We also find that conflict in the same buyer-seller relationship may increase due to powerful stakeholders that the organization faces. The conflicting demands that these stakeholders may place on how these buyer-seller relationships operate may cause that conflict issues are reacted to more severely than would happen if these stakeholders were not present. This implies that firms should be aware that partners facing relatively powerful stakeholders may be difficult to deal with due to the presence of powerful stakeholders. Our findings suggest especially a firm's customers are powerful stakeholders in the context of tour operators and travel agents.

\section{Limitations and Issues for Further Research}

As with nearly every other piece of research several limitations apply. A first limitation relates to the scope of the study. Our research identifies only the role that stakeholders have on conflict in a buyer-seller relationship. Conflict can also take place with organizations other than the supplier. For reasons of parsimony, we have not included such cases in our analysis but the basic model could be easily adjusted to accommodate this. Our focus on a single country bars us from identifying a possible role of the government as a stakeholder and country characteristics could give rise to idiosyncrasies that cannot be assessed using the current data. Also other stakeholders such as environmental groups or communities (See 
Maignan et al., 2005 for an overview of various stakeholder groups) could influence channel conflict.

As we conducted our study in a single country and a single industry, generalization of this study could be an issue. For example in certain industries customers may have very little power. By collecting data in other industries the generalizability of the findings could be tested.

Finally our study uses a single informant. Because the dependent variable of our study is manifest, and therefore more factual, the single source issue may be less of an issue (Summers, 2001). 


\section{Appendix 1: Measurement Scales}

\begin{tabular}{|c|c|c|}
\hline Construct & Items & Cronbach Alpha \\
\hline $\begin{array}{l}\text { Severity of } \\
\text { conflict reaction }\end{array}$ & $\begin{array}{l}\text { Our response to this conflict was firm. } \\
\text { Our response to this conflict was uncompromising. } \\
\text { Our response to this conflict was tough. } \\
\text { Our response to this conflict was decisive. }\end{array}$ & .70 \\
\hline Supplier power & $\begin{array}{l}\text { This supplier is more powerful than us. } \\
\text { In our relationship with this organization they have more } \\
\text { power } \\
\text { This organization can force decisions upon us }{ }^{\mathrm{a}} \text {. }\end{array}$ & .78 \\
\hline Power customers & $\begin{array}{l}\text { The customers are more powerful than us. } \\
\text { In our relationship with our customers they have more power } \\
\text { The customers can force decisions upon us. }\end{array}$ & .84 \\
\hline Power competitors & $\begin{array}{l}\text { The competitors are more powerful than us. } \\
\text { In our relationship with our competitors they have more } \\
\text { power. } \\
\text { The competitors can force decisions upon us. }\end{array}$ & .86 \\
\hline Power industry & $\begin{array}{l}\text { The industry association is more powerful than us. } \\
\text { In our relationship with the industry association they have } \\
\text { more power. } \\
\text { The industry association can force decisions upon us. }\end{array}$ & .79 \\
\hline $\begin{array}{l}\text { Legitimacy } \\
\text { customers }\end{array}$ & $\begin{array}{l}\text { It would provide legitimacy to us with respect to our } \\
\text { customers. } \\
\text { The best companies behave like this towards our customers. } \\
\text { It would portray us towards customers as an organization that } \\
\text { reacts strongly to conflicts. }\end{array}$ & .91 \\
\hline $\begin{array}{l}\text { Legitimacy } \\
\text { competitors }\end{array}$ & $\begin{array}{l}\text { It would provide legitimacy to us with respect to our } \\
\text { competitors. } \\
\text { The best competitors behave like this. } \\
\text { It would portray us towards our competitors as an } \\
\text { organization that reacts strongly to conflicts. }\end{array}$ & .88 \\
\hline $\begin{array}{l}\text { Legitimacy } \\
\text { industry }\end{array}$ & $\begin{array}{l}\text { It would provide legitimacy to us with respect to the industry } \\
\text { association. } \\
\text { The best companies within the industry association behave } \\
\text { like this. } \\
\text { It would portray us towards the industry association as an } \\
\text { organization that reacts strongly to conflicts. }\end{array}$ & .87 \\
\hline Partner attribution & $\begin{array}{l}\text { The supplier undertook the action because they tend look out } \\
\text { for their own interests, not ours. } \\
\text { The supplier is self-centered, and this accounts for their action } \\
\text { that led to conflict. } \\
\text { The supplier's act that led to conflict was intended to benefit } \\
\text { them, not ours. }\end{array}$ & .89 \\
\hline $\begin{array}{l}\text { External } \\
\text { attribution }\end{array}$ & $\begin{array}{l}\text { Competitive conditions forced the supplier to take the action } \\
\text { that led to conflict. } \\
\text { The behavior of our supplier leading to the conflict was } \\
\text { understandable given the market conditions in our area. } \\
\text { The current environment was responsible for actions of the } \\
\text { supplier leading to conflict. }\end{array}$ & .79 \\
\hline \multicolumn{3}{|c|}{$\begin{array}{l}\text { Note: all items were measured using a seven-point Likert scales ranging from completely disagree to completely } \\
\text { agree. }\end{array}$} \\
\hline
\end{tabular}




\section{References}

Agle, B. R., Mitchell, R. K. \& Sonnenfeld, J. A. (1999). Who Matters to CEOs? An Investigation of Stakeholder Attributes and Salience, Corporate Performance, and CEO Values. Academy of Management Journal, $42,507-525$.

Anderson, J. C., Håkansson, H. \& Johanson, J. (1994). Dyadic Business Relationships within a Business Network Context. Journal of Marketing, 58, 1-15.

Antia, K. D. \& Frazier, G. L. (2001). The Severity of Contract Enforcement in Interfirm Channel Relationships. Journal of Marketing, 65, 67-81.

Armstrong, J. S. \& Overton, T. S. (1977). Estimating Nonresponse Bias in Mail Surveys. Journal of Marketing Research, 14, 396-403.

Berman, S. L., Wicks, A. C., Kotha, S. \& Jones, T. M. (1999). Does stakeholder orientation matter? The relationship between stakeholder management models and firm financial performance. Academy of Management Journal, 42, 488-506.

Brown, J. R. \& Day, R. L. (1981). Measures of Manifest Conflict in Distribution Channels. Journal of Marketing Research, 18, 263-274.

Deephouse, D. L. (1996). Does Isomorphism Legitimate? Academy of Management Journal, 39, 1024-1039.

Dillman, D. A. (2000) Mail and Internet Surveys, New York, John Wiley \& Sons, Inc.

Dimaggio, P. J. \& Powell, W. W. (1983). The Iron Cage Revisited: Institutional Isomorphism and Collective Rationality in Organizational Fields. American Sociological Review, 46, 147-160.

Fornell, C. \& Larcker, D. F. (1981). Structural Equation Models with Unobservable Variables and Measurement Error: Algebra and Statistics. Journal of Marketing Research, 18, 382-388.

Frazier, G. L. (1983). Interorganizational Exchange in Marketing Channels: A Broadened Perspective. Journal of Marketing, 47, 68-78.

Frazier, G. L. (1999). Organizing and Managing Channels of Distribution. Journal of the Academy of Management Science, 27, 226-240.

Freeman, R. E. (1984) Strategic Management: A Stakeholder Approach, Boston, Pitman.

Frooman, J. (1999). Stakeholder Influence Strategies. Academy of Management Review, 24, 191-205.

Ganesan, S. (1993). Negotiation Strategies and the Nature of Channel Relationships. Journal of Marketing Research, 30, 183-203. 
Gaski, J. F. (1984). The Theory of Power and Conflict in Channels of Distribution. Journal of Marketing, 48, 929.

Grewal, R., Comer, J. M. \& Mehta, R. (2001). An Investigation into the Antecedents of Organizational Participation in Business-to-Business Electronic Markets. Journal of Marketing, 65, 17-33.

Grewal, R. \& Dharwadkar, R. (2002). The Role of the Institutional Environment of Marketing Channels. Journal of Marketing, 66, 82-97.

Gundlach, G. T. \& Cadotte, E. R. (1994). Exchange Interdependence and Interfirm Interaction: Research in a Simulated Channel Setting. Journal of Marketing Research, 31, 516-532.

Harrison, J. S. \& Freeman, R. E. (1999). Stakeholders, Social Responsibility, and Performance: Empirical Evidence and Theoretical Perspectives. Academy of Management Journal, 42, 479-485.

Hibbard, J. D., Kumar, N. \& Stern, L. W. (2001). Examining the Impact of Destructive Acts in Marketing Channel Relationships. Journal of Marketing Research, 38, 45-61.

Jap, S. D. \& Ganesan, S. (2000). Control Mechanisms and the Relationship Life Cycle: Implications for Safeguarding Specific Investments and Developing Commitment. Journal of Marketing Research, 37, $227-245$.

Kumar, N., Scheer, L. K. \& Steenkamp, J.-B. E. M. (1998). Interdependence, Punitive Capability, and the Reciprocation of Punitive Actions in Channel Relationships. Jounal of Marketing Research, 35, 225 235 .

Kumar, N., Stern, L. W. \& Anderson, J. C. (1993). Conducting Interorganizational Research Using Key Informants. Academy of Management Journal, 36, 1633-1651.

Lawler, E. J., Ford, R. S. \& Blegen, M. A. (1988). Coercive Capability in Conflict: A test of Bilateral Deterrence versus Conflict Spiral Theory. Social Psychology Quarterly, 51, 93-107.

Levy, M. \& Grewal, D. (2000). Supply Chain Management in a Networked Economy. Journal of Retailing, 76, 415-429.

Maignan, I. \& Ferrell, O. C. (2004). Corporate Social Responsibility and Marketing: An Integrative Framework. Journal of the Academy of Marketing Science, 32, 3-19.

Maignan, I., Ferrell, O. C. \& Ferrell, L. (2005). A stakeholder model for implementing social responsibility in marketing. European Journal of Marketing, 39, 956-977.

Maignan, I. \& Mcalister, D. T. (2003). Socially Responsible Organizational Buying: How Can Stakeholders Dictate Purchasing Policies? Journal of Macromarketing, 23, 78-89. 
Marketing Science Institute (2006) Research Priorities: A Guide to MSI Research Priorities and Procedures.

Mitchell, R. K., Agle, B. R. \& Wood, D. J. (1997). Toward a Theory of Stakeholder Identification and Salience: Defining the Principle of Who and What Really Counts. Academy of Management Review, 22, 853886.

Narver, J. C. \& Slater, S. F. (1990). The Effect of a Market Orientation on Business Profitability. Journal of Marketing, 54, 20-35.

Oliver, C. (1991). Strategic Responses to Institutional Processes. Academy of Management Review, 16, 145-179.

Scheer, L. K. \& Stern, L. W. (1992). The Effect of Influence Type and Performance Outcomes on Attitude Toward the Influencer. Journal of Marketing Research, 29, 128-142.

Schul, P. L. \& Babakus, E. (1988). An Examination of the interfirm Power-Conflict Relationship: The Intervening Role of the Channel Decision Structure. Journal of Retailing, 64, 381-404.

Suchman, M. C. (1995). Managing Legitimacy: Strategic and Institutional Approaches. Academy of Management Review, 20, 571-610.

Summers, J. O. (2001). Guidelines for Conducting Research and Publishing in Marketing: From Conceptualization Through the Review Process. Journal of the Academy of Marketing Science, 29, $405-415$

Voss, Z. G., Voss, G. B. \& Moorman, C. (2005). An empirical examination of the complex relationship between entrepreneurial orientation and stakeholder support. European Journal of Marketing, 39, 1132-1150. 
Table 1: Correlations, Means, and Variances of the Constructs

\begin{tabular}{|c|c|c|c|c|c|c|c|c|c|c|}
\hline \multicolumn{11}{|c|}{ CORRELATION MATRIX } \\
\hline & 1 & 2 & 3 & 4 & 5 & 6 & 7 & 8 & 9 & 10 \\
\hline 1. Severity of conflict reaction & $0.50^{\mathrm{a}}$ & & & & & & & & & \\
\hline 2. Supplier power & -0.25 & 0.67 & & & & & & & & \\
\hline 3. Power industry & -0.01 & 0.20 & 0.70 & & & & & & & \\
\hline 4. Power competitors & -0.18 & 0.39 & 0.16 & 0.77 & & & & & & \\
\hline 5. Power customers & 0.11 & 0.12 & -0.09 & 0.27 & 0.80 & & & & & \\
\hline 6. Legitimacy industry & 0.13 & 0.17 & 0.06 & 0.10 & 0.03 & 0.81 & & & & \\
\hline 7. Legitimacy competitors & 0.24 & 0.13 & 0.12 & 0.03 & 0.14 & 0.67 & 0.82 & & & \\
\hline 8. Legitimacy customers & 0.11 & 0.02 & 0.16 & 0.08 & 0.21 & 0.64 & 0.66 & 0.87 & & \\
\hline 9. Partner attribution & 0.14 & 0.29 & -0.03 & 0.08 & 0.04 & -0.05 & 0.06 & -0.06 & 0.83 & \\
\hline 10. External attribution & 0.07 & 0.12 & 0.08 & 0.16 & -0.19 & 0.18 & 0.12 & 0.12 & -0.04 & 0.68 \\
\hline Mean & 19.77 & 14.09 & 14.47 & 10.06 & 12.55 & 10.77 & 12.04 & 12.04 & 15.07 & 10.59 \\
\hline Standard deviation & 3.73 & 4.28 & 3.77 & 4.00 & 3.94 & 4.10 & 3.95 & 4.20 & 3.94 & 4.16 \\
\hline \multicolumn{11}{|c|}{ POPULATION DESCRIPTORS } \\
\hline Number of organizations in SIC & les 4724 & 4725 & \\
\hline Organizational size & & & \multirow{4}{*}{\multicolumn{8}{|c|}{$\begin{array}{l}\text { 1-10 employees } 72 \%, 11-100 \text { employees } 23 \%, 101 \text { or more employees } 5 \% \text {. } \\
\text { limited liability } 54 \% \text {, sole proprietorship } 32 \% \text {, partnerships } 4 \% \text {, other (including foreign legal forms) } 10 \% \\
\text { average }=13.89 \text {, standard deviation }=18.40 \text {, minimum }=0 \text {, maximum }=184 \\
\text { SAMPLE DESCRIPTORS }\end{array}$}} \\
\hline Legal form & & & & & & & & & & \\
\hline \multirow{2}{*}{\multicolumn{3}{|c|}{ Age of the organization (rounded to whole years) }} & & & & & & & & \\
\hline & & & & & & & & & & \\
\hline \multicolumn{3}{|c|}{ Tenure of informant at company } & \multicolumn{8}{|c|}{ average $=10.33$, standard deviation $=8.49$, minimum $=1 / 2$, maximum $=41$} \\
\hline \multicolumn{3}{|c|}{ Self-rated competency of informant } & \multicolumn{8}{|c|}{ average $=5.74$, standard deviation $=.94$, minimum $=1$, maximum 7} \\
\hline Organizational size & & & \multicolumn{8}{|c|}{$1-10$ employees $69 \%, 11-100$ employees $28 \%, 101$ or more employees $3 \%$. } \\
\hline \multicolumn{3}{|l|}{ Function of informant } & \multicolumn{8}{|c|}{ director or CEO $63 \%$, marketing or sales manager $19 \%$, other $17 \%$. } \\
\hline
\end{tabular}


Table 2: Regression Analysis Results

\begin{tabular}{|c|c|c|c|}
\hline $\begin{array}{l}\text { Dependent variable: } \\
\text { Severity of conflict reaction }\end{array}$ & $\begin{array}{l}\text { Expected } \\
\text { sign }\end{array}$ & $\begin{array}{l}\text { Standardized } \\
\text { coefficient }\end{array}$ & t-value \\
\hline Constant & & & $6.31 * * *$ \\
\hline Supplier power & - (H1) & -0.37 & $-3.73 * * *$ \\
\hline Power industry & $+(\mathrm{H} 2 \mathrm{a})$ & 0.10 & 1.07 \\
\hline Power competitors & $+(\mathrm{H} 2 \mathrm{~b})$ & -0.15 & -1.55 \\
\hline Power customers & $+(\mathrm{H} 2 \mathrm{c})$ & 0.22 & $2.28 * *$ \\
\hline Legitimacy industry & $+(\mathrm{H} 3 \mathrm{a})$ & 0.13 & 0.98 \\
\hline Legitimacy competitors & $+(\mathrm{H} 3 \mathrm{~b})$ & 0.26 & $2.05 * *$ \\
\hline Legitimacy customers & $+(\mathrm{H} 3 \mathrm{c})$ & -0.19 & -1.49 \\
\hline \multicolumn{4}{|l|}{ Control variables } \\
\hline Partner attribution & + & 0.24 & $2.64 * * *$ \\
\hline External attribution & + & 0.15 & $1.65^{*}$ \\
\hline F-value $(9,106)$ & 3.85 & & \\
\hline Observations & 116 & & \\
\hline R-squared & 0.25 & & \\
\hline Adjusted R-squared & 0.18 & & \\
\hline Root MSE & 3.37 & & \\
\hline
\end{tabular}

\section{Endnotes:}

1: See http://news.bbc.co.uk/1/hi/business/6337275.stm, accessed 3/11/2007.

2: See http://www.businessweek.com/technology/content/nov2003/tc20031118_6129_tc047.htm, accessed 6/3/2007.

3: See http://www.theregister.co.uk/2000/05/09/virgin_carrys_out_payment_freeze/ accessed 24th July 2006 